\title{
DAMPAK LINGKUNGAN KERJA DAN MOTIVASI KERJA TERHADAP KEPUASAAN KARYAWAN PERUSAHAAN LOGISTIK
}

\author{
Achmad Budi Saifudin', \\ Didin Fatihudin ${ }^{2}$ \\ Mochamad Mochklas ${ }^{3}$
}
Fakultas Ekonomi dan Bisnis Universitas Muhammadiyah Surabaya, Jawa Timur, Indonesia ${ }^{1,2,3}$
Email: mmochklas@fe.um-surabaya.ac.id

\begin{abstract}
Knowing and analyzing the impact of the work environment and work motivation on employee job satisfaction in logistics companies is very important. High employee job satisfaction will have an impact on increasing employee productivity and performance. This research method with quantitative, population and sample are employees of logistics company PT. Cipta Krida Bahari. All incoming data are processed using SPSS 20. The results of this study are partially positive and significant work environment and work motivation, and simultaneously work environment and work motivation have a positive and significant effect on employee job satisfaction.
\end{abstract}

Keywords: Work Environment; Work Motivation; Job Satisfaction.

\begin{abstract}
ABSTRAK
Mengetahui dan menganalisa dampak lingkungan kerja dan motivasi kerja terhadap kepuasan kerja karyawan peusahaan logistik sangat penting. Kepuasan kerja karyawan yang tinggi akan berdampak pada meningkatnya produktivitas dan kinerja karyawan. Metode penelitian ini dengan kuantitatif, populasi dan sampelnya adalah karyawan perusahaan logistik PT. Cipta Krida Bahari. Semua data yang masuk diolah dengan menggunakan SPSS 20. Hasil penelitian ini secara parsial lingkungan kerja dan motivasi kerja pengaruh positif dan signifikan, dan secara simultan lingkungan kerja dan motivasi kerja berpengaruh positif dan signifikan terhadap kepuasan kerja karyawan.
\end{abstract}

Kata Kunci : Lingkungan kerja; Motivasi kerja; kepuasan kerja. 
Achmad Budi Saifudin, Didin Fatihudin, dan Mochamad Mochklas. Dampak Lingkungan Kerja....

\section{PENDAHULUAN}

Persaingan bisnis saat ini menjadi kompettitif, kareni itu perlu mengoptimalkan semua sumber daya seperti modal. Struktur kerja, motode kerja, pemasaran dan karyawaan. Karyawan merupakan salah satu faktor terpenting di perusahaan, menurut Atmaja \& Ratnawati (2018), bahwa salah satu faktor penyebab tidak berkembangnya suatu perusahaan adalah sumber daya manusia di perusahaan yang tidak berkualitas. Untuk menciptakan keunggulan kompetitif, program pengembangan sumber daya manusia diperlukan secara berkelanjutan, jelas, dan konsisten (Kalangi, 2015).

Tiap karyawan tingkat kepuasan kerjanya berbeda, hal ini sesuia dengan karakteristik masing-masing individu. Kepuasan kerja menurut Mangkunegara (2015:117) merupakan perasaan yang ada pada diri karyawan yang mendukung atau tidak mendukung karyawan terhadap kondisi pekerjaan mereka. Terdapat beberapa faktor yang berpengaruh terhadap kepuasan kerja karyawan diantaranya balas jasa, penempatan kerja sesuai keahlian, berat ringan pekerjaan, suasan dan lingkungan kerja, peralatan penunjang pekerjaan, sikap pimpinan dan sifat pekerjaan (Hasibuan, 2005:220).

Meningkatkan kepuasan kerja sangat penting bagi perusahaan, karena kepuasan kerja berpengaruh positif terhadap motivasi kerja karyawan (Adely, 2017), berpengaruh langsung pada disiplin kerja (Divine et al., 2017), meningkatkan kinerja karyawan (Damayanti et al., 2018), meningkatkan produktivitas karyawan (Adiwinata \& Sutanto, 2014) dan meningkat secara optimal 
hasil kerja karyawan sehingga perusahaan dapat mencapai kesuksesan (Muayyad \& Gawi, 2016). Ketika karyawan merasa tidak puas dalam bekerja, maka akan mengakibatkan tingkat turnover naik (Susilo \& Satrya. 2019).

Menurut Nitisemito (dalam (Nitisemito dalam Suwardi \& Daryanto, 2018: 209), bahwa lingkungan kerja merupakan kondisi yang mengelilingi karyawan saat bekerja dan dapat mempengaruhi karyawan dalam menyelesaikan pekerjaannya. Lingkungan kerja mempengaruhi kepuasan karyawan (Aruan \& Fakhri, 2015), Husni et al., (2018), Sitinjak (2018), Mochklas et al.. (2019) dan Wibowo et al., (2020). Sedangkan menurut (Marta \& Budi, 2019), lingkungan sekitar karyawan bekerja yang berupa fisik tidak berpengaruh secara signifikan terhadap kepuasan kerja karyawan.

Afandi (2016: 12) menyatakan bahwa motivasi merupakan keinginan yang timbul dari dalam diri seseorang karena antusiasme, inspirasi dan dorongan untuk melaksanakan kegiatan dengan ikhlas, kesenangan dan ketulusan sehingga hasil dari suatu kegiatan yang menjadikan untuk mendapatkan hasil dan kualitas yang baik

Motivasi kerja menurut Diyanti et al., (2017) secara signifikan memiliki pengaruh terhadap kepuasan kerja, karena dalam motivasi terdapat nilai koefisien parameter nyata dan positif. Ini mencerminkan motivasi kerja melalui indikatornya, jika motivasi kerja meningkat akan dapat meningkatkan kepuasan kerja. Beberapa hasil penelitian sebelumnya (Diyanti et al., 2015), Parimita et al., (2018), secara positif dan signifikan motivasi karyawan dalam melakukan pekerjaannya memiliki 
Achmad Budi Saifudin, Didin Fatihudin, dan Mochamad Mochklas. Dampak Lingkungan Kerja....

pengaruh positif dan signifikan terhadap kepuasan kerja. Sedangkan hasil penelitian Mutia (2018), motivasi kerja tidak memiliki pengaruh yang positif dan signifikan terhadap kepuasan kerja.

Sumber kepuasan yang ada pada diri karyawan secara subyektif akan menentukan kepuasan kerja, meskipun tidak ada keseragaman untuk kepuasan kerja dan tidak terdapat prinsip yang mengikat kepuasan karyawan dalam bekerja. Dari penelitian Dhermawan et al., (2012) menyebautkan motivasi dan lingkungan kerja tidak berpengaruh cecara signifikan terhadap kepuasan kerja, walaupun karyawan memiliki motivasi kerja yang baik.

Menganalisa dampak lingkungan dimana karyawan bekerja dan motivasi karyawan saat bekerja dengan kepuasan kerja sangat penting, karyawan yang bekerja di perusahaan logistik sangat penting sekali. PT. Cipta Krida Bahari merupakan perusahaan logistik yang merupakan perusahaan jasa pengiriman barang, yang berguna untuk memudahkan pelaku usaha di seluruh Indonesia. Dengan menganalisa kepuasan kerja karyawaan ini, akan dapat menjadi masukan bagi perusahaan dalam perencanaan pengembangan Sumber Daya Manusia ke depannya.

Lingkungan kerja. Nitisemito dalam Suwardi (2018:209), menyatakan lingkungan kerja adalah sesuatu yang yang ada di sekitar karyawan saat menjalan pekerjaan dan dapat mempengaruhi karyawan dalam menjalankan aktifitas pekerjaannya (Nitisemito dalam Suwardi, 2018:209). Menurut Sedarmayanti (2011:28), lingkungan kerja ditandai dengan adanya pencayahaan, suhu, 
kelembaban udara, sistem sirkulasi udara, kebisingan, bau dan pengaturan warna ditempat kerja.

Motivasi kerja. Motivasi menurut Sutrisno (2016:146) merupakan faktor pendorong karyawan untuk melakukan pekerjaan yang telah diberikan kepadanya. Dengan motivasi ini perilaku karyawan dalam me;laksanakan pekerjaannya akan dipandu. Menurut Afandi (2016: 12), motivasi kerja merupakan keinginan yang timbul pada diri karyawan karena semangat, inspirasi serta dorongan untuk melakukan pekerjaan dengan tulus dan senang sehingga mencapai hasil yang baik dan berkualitas.

Kepuasan Kerja. Robbins (2015:139) menyatakan bahwa kepuasan kerja meruapakan sikap karyawan secara umum dalam yang dapat mempengaruhi pekerjaan yang tugaskan kepadanya. Setiap individu mempunyai tingkat kepuasan yang tidak sama. Tingkat kepuasan kerja karyawan yang tinggi dalam melakukan pekerjaannya akan menunjukkan sikap yang positif, sebaliknya karyawan yang memiliki kepuasan kerja rendah dalam melakukan pekerjaannya akan menunjukan sikap yang negatif. akan menunjukkan sikap yang negatif dalam bekerja. Beberapa aspek yang berpengaruh dalam kepuasan kerja menurut Damayanti et al., (2018) adalah pekerjannya itu sendiri, pendapatan, peluamh promosi dan kerjasama.

Kerangka konsep penelitian ini ditunjukan oleh Gambar 1, yang menjelaskan hubungan lingkungan kerja dengan kepuasan kerja, menjelaskan hubungan motivasi kerja dengan kepuasan kerja, dan menjelaskan hubungan lingkungan kerja 
dan motivasi kerja terhadap kepuasan kerja. Dari kerangka konsep penelitian akan dapat ditarik kesimpulan yang dapat digeneralisasikan.

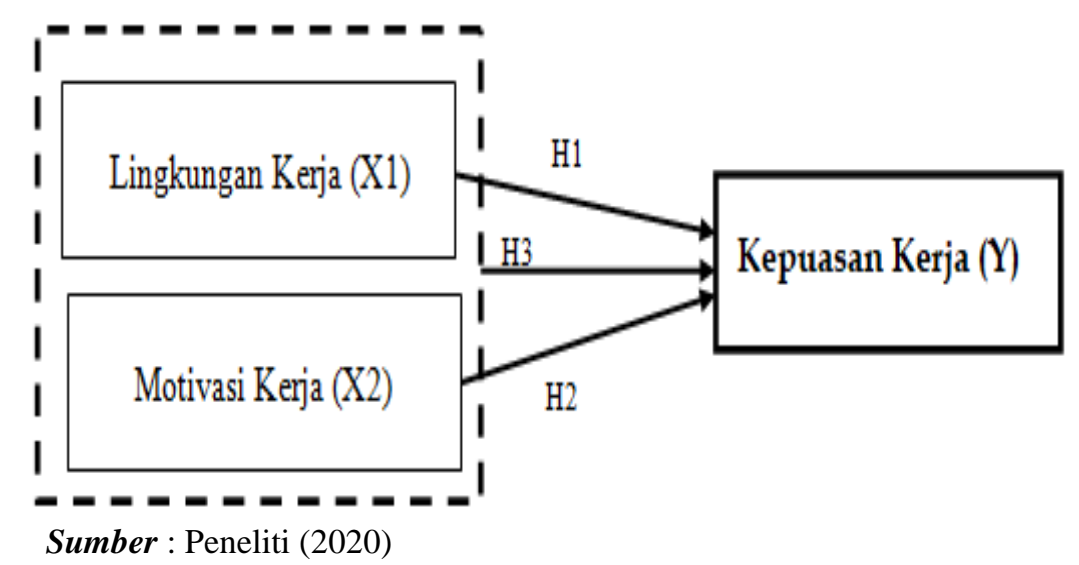

\section{Gambar 1. \\ Kerangka konsep penelitian}

Dari kerangka konsep penelitian Gambar 1, hipotesisi penelitian adalah sebagai beeriku:

H1: Secara parsial lingkungan kerja berdampak terhadap kepuasan kerla

H2: Seacara parsal motivasi kerja berdampak terhadap kepuasan kerja

H3: Secara simultan lingkungan kerja dan motivasi kerja berdampak terhadap kepuasan kerja

\section{METODE PENELITIAN}

Metode kuantitatif digunakan sebagai pendekatan penelitian ini yang didasarkan pada azaz positivisme (Sugiyono, 2017:30), dimana peneliti melakukan penelitian pada populasi dan sampel tertentu dengan menyebarkan kuesioner. Pertanyaan dalam kuesioner menggunakan skala linkert, data yang masuk akan 
dianalisa dengan mengunakan metode statistik yang bertujuan menguji hipotesis. Analisa data secara statistik menggunakan program SPSS versi 20.

Populasi dan sampel penelitian ini adalah karyawan yang bekerja di PT. Cipta Krida Bahari sebanyak 50 orang, terdiri dari 43 orang pria dan 7 orang wanita. PT. Cipta Krida Bahari merupakan perusahaan penyedia jasa pengiriman barang, untuk memudahkan para pelaku usaha di Indonesia dalam mengantarkan barang dan jasa.

\section{HASIL DAN PEMBAHASAN}

Hasil perhitungan nilai validitas X1, X2 dan Y dengan program SPSS 20 diperoleh nilai r-hitung adalah 0,2732 dengan nilai signifikansi 0,5. Dari hasi tersebut maka nilai r-hitung 0,2732>0,05, maka dapat disimpulkan bahwa variabel $\mathrm{X} 1, \mathrm{X} 2$ dan Y adalah variabel yang valid.

Hasil uji reliabilitas dinyatakan valid bila r-hitung > r-Tabel dengan nilai signifikansi 0,5. Hasil uji reliabilitas ditunjukkan oleh Tabel 1.

Tabel 1.

Uji Reliabilitas

\begin{tabular}{cccc}
\hline Variabel & Cronbach's alpha & $\begin{array}{c}\text { Minimum of Cronbach } \\
\text { Alpha Required }\end{array}$ & Keterangan \\
\hline X1 & 0.729 & 0.6 & Reliability \\
X2 & 0.840 & 0.6 & Reliability \\
Y & 0.707 & 0.6 & Reliability \\
\hline
\end{tabular}

Sumber: Olahan data peneliti (2020)

Dari data Tabel 1, variabel X1, X2 dan Y dinyatakan reliabel karena nilai Cronbach Alpha dari masing-masing variabel diatas nilai minimum $(0,6)$. 
Tabel 2.

Hasil Uji Regresi Linier Berganda

\begin{tabular}{|c|c|c|c|c|c|c|}
\hline \multicolumn{7}{|c|}{ Coefficients $^{a}$} \\
\hline & \multirow[t]{2}{*}{ Model } & \multicolumn{2}{|c|}{$\begin{array}{c}\text { Unstandardized } \\
\text { Coefficients }\end{array}$} & \multirow{2}{*}{$\begin{array}{c}\text { Standardized } \\
\text { Coefficients } \\
\text { Beta }\end{array}$} & \multirow[t]{2}{*}{$\mathrm{t}$} & \multirow[t]{2}{*}{ Sig. } \\
\hline & & $\mathrm{B}$ & Std. Error & & & \\
\hline \multirow[t]{3}{*}{1} & (Constant) & .311 & .545 & & .570 & .572 \\
\hline & Lingkungan Kerja (X1) & .461 & .138 & .3773 & .332 & .002 \\
\hline & Motivasi Kerja (X2) & .456 & .112 & .4584 & 4.057 & .000 \\
\hline
\end{tabular}

a. Dependent Variable: Kepuasan Kerja (Y1)

Sumber: Olahan data peneliti (2020)

Dari Tabel 2 diperoleh persamaam regresi linier berganda:

$\mathrm{Y}=0,311+0,377 \mathrm{X} 1+0,458 \mathrm{X} 2$

Interprestasi dari model persaman regresi linier berganda adalah 1). Konstanta sebesar 0,311 satuan menunjukkan bahwa jika variabel independen $=0$, variabel dependen masih memiliki nilai 0,311 satuan. 2). Nilai koefisien (X1) lingkungan kerja sebesar 0,377 satuan, mempunyai arti bila variabel lingkungan kerja naik maka kepuasan kerja akan meningkat sebesar 0,377 satuan. Dengan asumi bahwa ariabel motivasi kerja konstan. 3). Nilai koefisien (X2) motivasi kerja sebesar 0,458 satuan, mempunyai makna jika motivasi kerja naik maka kepusaan kerja juga meningkat sebesar 0,377 satuan. Dengan asumsi variabel lingkungan kerja konstan.

Tabel 3.

\section{Hasil Uji R ${ }^{2}$}

\begin{tabular}{|c|c|c|c|c|c|c|}
\hline \multicolumn{7}{|c|}{ Coefficients $^{a}$} \\
\hline & \multirow[t]{2}{*}{ Model } & \multicolumn{2}{|c|}{$\begin{array}{c}\text { Unstandardized } \\
\text { Coefficients }\end{array}$} & \multirow{2}{*}{$\begin{array}{c}\text { Standardized } \\
\text { Coefficients } \\
\text { Beta }\end{array}$} & \multirow[t]{2}{*}{$\mathrm{t}$} & \multirow[t]{2}{*}{ Sig. } \\
\hline & & $\mathrm{B}$ & Std. Error & & & \\
\hline \multirow[t]{3}{*}{1} & (Constant) & .311 & .545 & & .570 & .572 \\
\hline & Lingkungan Kerja (X1) & .461 & .138 & .3773 & .332 & .002 \\
\hline & Motivasi Kerja (X2) & .456 & .112 & .4584 & 4.057 & .000 \\
\hline
\end{tabular}


Berdasarkan Tabel 3, dapat diketahui bahwa nilai koefisien determinasi (R2) adalah 0,470. Nilai ini mempunyai arti bahwa variabel independen lingkungan kerja fdan motivasi kerja berpengaruhi terhadap variabel kepuasan kerja sebesar $47 \%$ dan sisanya 53\% dijelaskan oleh variabel lain diluar model.

Untuk mengetahui sejauh mana masing-masing variabel indepen secara parsial mempengaruhi variabel dependen perlu dilakukan uji t. Hasil uji t ditunjukan oleh Tabel 4.

Tabel 4.

\section{Hasil uji t}

\begin{tabular}{|c|c|c|c|c|c|c|}
\hline \multicolumn{7}{|c|}{ Coefficients $^{a}$} \\
\hline & \multirow[t]{2}{*}{ Model } & \multicolumn{2}{|c|}{$\begin{array}{c}\text { Unstandardized } \\
\text { Coefficients }\end{array}$} & \multirow{2}{*}{$\begin{array}{c}\text { Standardized } \\
\text { Coefficients } \\
\text { Beta }\end{array}$} & \multirow[t]{2}{*}{$t$} & \multirow[t]{2}{*}{ Sig. } \\
\hline & & $B$ & Std. Error & & & \\
\hline \multirow[t]{3}{*}{1} & (Constant) & .311 & .545 & & .570 & .572 \\
\hline & Lingkungan Kerja (X1) & .461 & .138 & .377 & 3.332 & .002 \\
\hline & Motivsasi Kerja (X2) & .456 & .112 & .458 & 4.057 & .000 \\
\hline
\end{tabular}

a. Dependent Variable: Kepuasan Kerja (Y1)

Sumber: Olahan data peneliti (2020)

Dari hasul uji t Tabel 4, dapat diketahui bahwa variabel lingkungan kerja memiliki nilai signifikan $0,002<0,05$ yang berarti $\mathrm{H} 1$ diterma. Hasil ini menunjukan bahwa lingkungan kerja (X1) memiliki pengaruh parsial terhadap kepuasan kerja (Y). Dan variabel motivasi kerja (X2) diketahu nilai signifikan $0,000<0,05$ yang berarti H2 diterima. Dari hasil ini menunjukkan bahwa motivasi kerja (X2) memiliki pengaruh parsial terhadap kepuasan kerja (Y). 
Achmad Budi Saifudin, Didin Fatihudin, dan Mochamad Mochklas. Dampak Lingkungan Kerja....

Untuk mengetahui pengaruh secara simultan antara variabel lingkungan kerja dan motivasi kerja perlu dilakukan uji F. Hasil uji F, ditunjukan Tabel 5.

Tabel 5.

Hasil Uji F

\begin{tabular}{llcccc}
\multicolumn{7}{c}{ ANOVA $^{\text {b }}$} \\
\hline \multicolumn{1}{c}{ Model } & Sum of Squares & $d f$ & Mean Square & F & Sig. \\
\hline 1 Regression & 3.199 & 2 & 1.600 & 20.812 & $.000^{\mathrm{a}}$ \\
Residual & 3.613 & 47 & .077 & & \\
Total & 6.812 & 49 & & & \\
\hline
\end{tabular}

Sumber: Olahan data peneliti (2020)

Berdasarkan data ini bahwa nilai signifikan 0,000 <0,05, H3 diterima, yang berarti lingkungan kerja (X1) dan motivasi kerja (X2) secara simultan berdampak pada pekerjaan (Y). Dari hasil uji hipotesis, hasil penelitian ini menunjukkan bahwa lingkungan kerja berpengaruh terhadap kepuasan kerja, motivasi kerja berpengaruh terhadap kepuasan kerja, dan lingkungan kerja dan motivasi kerja berpengaruh terhadap pekerjaan.

\section{Tabel 6. \\ Temuan Penelitian}

\begin{tabular}{clcc}
\hline Hipotesis & Uraian & Temuan & Hasil \\
& & & \\
\hline 1 & Lingkungan kerja berpengaruh terhadap kepuasan kerja & 0,377 & Diterima \\
2 & Motivasi kerja berpengaruh terhadap kepuasan kerja & 0,002 & \\
& & $\mathrm{Sig}, 000$ & Diterima \\
3 & Lingkungan kerja dan motivasi kerja secara bersama- & 0,470 & Diterima \\
& sama berpengaruh terhadap kepuasan kerja & Sig .000 & \\
\hline
\end{tabular}

Sumber : Hasil Olah Data Penelti (2020)

Dampak Lingkungan Kerja Terhadap Kepuasan Kerja. Dari analisa statistik diperoleh nilai t hitung sebesar 3,332. Nilai ini thitung 3,232 > t Tabel 2,01171 
dengan nilai signifikasi 0,002 $<0,05$, mempunyai makna bahwa lingkungan kerja memiliki dampak yang positif dan signifikan terhadap kepuasan kerja. Hipotesis pertama diterima.

Hasil penelitian ini memperkuat hasil penelitian sebelumnya Aruan \& Fakhri (2015), Husni et al., 2018, dan Sitinjak (2018), dimana para peneliti tersebut menyimpulakn lingkungan kerja memiliki pengaruh yang positif dan signifikan terhadap kepuasan kerja karyawan.

Implikasi dari temuan penelitian ini, perusahaan yang bergerak bidang logistik sangat penting untuk selalu memperhatikan dan memelihara secara terus menerus lingkungan kerja. Kondisi sekitar karyawan dalam beraktifitas yang semakin baik akan berdampak pada semakin meningkatnya rasa puas karyawan dalam bekerja di perusahaan tersebut. Kondisi lingkungan kerja ini tidak hanya sebatas lingkungan fisik saja perlu diperhatikan juga lingkungan non fisik. Dengan lingkungan kerja yang baik tidak hanya karyawan merasakan kepuasan dalam bekerja, karyawan akan merasa nyaman dan betah dalam bekerja.

Dampak Motivasi Kerja Terhadap Kepuasan Kerja. Hasil penelitian ini nilai t hitung 4,057 $>$ t Tabel 2,01174 dengan nilai signifikansi $0,000<0,05$, menunjukan bahwa motivasi kerja memiliki dampak yang positif dan signifikan terhadap kepuasan kerja. Hipotesis kedua diterima

Temuan penelitian ini memperkuat hasil penelitian Firdaus \& Sjahruddin (2019), yang menyatakan motivasi kerja secara positif dan signifikan berpengaruh terhadap kepuasan kerja. Tingkat motivasi karyawan yang tidak 
Achmad Budi Saifudin, Didin Fatihudin, dan Mochamad Mochklas. Dampak Lingkungan Kerja....

sama antara satu dengan lainnya, merupakan tantangan bagi perusahaan untuk dapat menumbuhkan terus menerus motivasi kerja karyawan.

Motivasi kerja berangsur-angsur akan menurun seiring dengan banyaknya pekerjaan dan permasalahn yang dihadapi karyawan, perusahaan berupaya agar dapat menumbuhkan motivasi karyawan. Menumbuhkan motivasi karyawan bisa dilakukan dengan pemberian reward bagi yang berprestasi, mengembangan jenjang karir yang jelas, dilibatkan karyawan dalam pengambilan keputusan dalam pekerjaan, dan masih banyak lainnya.

Dampak Lingkungan Kerja, Motivasi Kerja Terhadap Kepuasan Kerja. Dari hasil uji secara statisitik diperoleh nilai F hitung 20,812. Nilai F hitung 20,8012 lebih besar dari F Tabel 3,20 membuktikan secara simultan lingkungan kerja dan motivasi kerja memiliki dampak yang positif yang positif dan signifikan terhadap kepuasan kerja. Hipotesis ketiga diterima.

Temuan dari penelitian ini memperkuat penelitian Sudiarditha, Waspodo \& Triani (2016), berpengaruh positif dan signifikan lingkungan kerja dan motivasi terhadap kepuasan kerja. Penting bagi perusahaan menciptakan lingkungan kerja dan menumbuhkan motivasi karyawan dalam bekerja secara bersa-sama, sehingga dapat meningkatkan kepuasan kerja karyawan. Bila karyawan merasakan pekerjaannya menyenangkan dan menarik, tentu karyawan tersbut akan bersedia memberikan upaya yang maksimal untuk kepentingan perusahaan. Dengan kepuasan karyawaan yang tinggi produktifitas dan hasil kerja karyawan akan meningkat. 


\section{SIMPULAN DAN SARAN}

Dari hasil uji analisa data dan pembahasan penelitian dapat disimpulkan lingkungan kerja dan motivasi kerja karyawan secara parsial mempunyai dampak yang positif dan signifikan terhadap kepuasan kerja karyawan perusahaan logistik di PT. Cipta Krida Bahari. Kedua lingkungan kerja dan motivasi kerja secara simultan mempunyai dampak positif dan signifikan terhadap kepuasan kerja para karyawan perusahaan logistik di PT. Cipta Krida Bahari.

Kepuasan kerja dapat meningkata bila perusahaan memperhatikan lingkungan sekitar karyawan dalam menjalankan pekerjaannya dan motivasi kerja, dari penelitian ini variabel tersebut memiliki pengaruh $47 \%$ dalam miningkatkan kepuasan kerja karyawan, beberapa saran yang dapat dipertimbangkan oleh perusahaan logisitik agar kepuasan kerja karyawan meningkat perlu memelihara dan meningkatkan lingkungan dimana karyawan menjalankan aktivitas kerja serta motivasi para karyawan dalam bekerja. Untuk mengetahui lebih detail faktor-faktor yang mempengaruhi kepuasan kerja di perusahaan logistik, penelitian berikutnya bisa dilakukan di perusahaan yang sama dengan mengembangkan variabel lainnya seperti kepemimpinan atasan, evaluasi kerja, pendapatan,kerja sama antar karyawan.

\section{REFERENSI}

Adely, A.P. 2017. Pengaruh Kepemimpinan Dan Kepuasan Kerja Terhadap Motivasi Kerja Karyawan: Studi Pada Bank BJB Cabang Ciamis. Journal of Management Review, 1 (3): 107-112 
Achmad Budi Saifudin, Didin Fatihudin, dan Mochamad Mochklas. Dampak Lingkungan Kerja....

Adiwinata, I., \& Sutanto E.M. 2014. Pengaruh Kepuasan Kerja Dan Motivasi Kerja Terhadap Produktivitas Kerja Karyawan CV. Intaf Lumajang. AGORA, 2 (1)

Afandi, P. 2016. Concept dan Indikator Human Resource Manajemen For Manajemen Researth. Yogyakarta: Deepublish

Aruan, Q.S., \& Fakhri, M. 2015. Pengaruh Lingkungan Terhadap Kepuasan Kerja Karyawan Lapangan Departemen Grasberg Power Distribution PT. Freeport Indonesia. Jurnal Modus, 27 (2): 141-162

Atmaja, H.E., \& Ratnawati, S. 2018. Pentingnya Manajemen Sumber Daya Manusia Untuk Meningkatkan Usaha Kecil Menengah. Riset Ekonomi Manajemen, 2 (1): 21-35

Damayanti, R., Hanafi, A., \& Cahyadi, A. 2018. Pengaruh Kepuasan Kerja Terhadap Kinerja Karyawan (Studi Kasus Karyawan Non Medis RS Islam Siti Khadijah Palembang). Jembatan: Jurnal Ilmiah Manajemen, 15 (2): 7586

Dhermawan, A.A.N.B., Sudibya, I.G.A., \& Utama, I.W.M. 2012. Pengaruh Motivasi, Lingkungan Kerja, Kompetensi, Dan Kompensasi Terhadap Kepuasan Kerja Dan Kinerja Pegawai Di Lingkungan Kantor Dinas Pekerjaan Umum Provinsi Bali. Jurnal Manajemen, Strategi Bisnis, Dan Kewirausahaan, 6 (2): 173-184

Diyanti, Hubeis, M., \& Affandi, M.J. 2017. Pengaruh Motivasi Kerja Dan Iklim Kerja Terhadap Kepuasan Kerja Dan Implikasinya Terhadap Kinerja Tenaga Kependidikan Institut Pertanian Bogor. Jurnal Aplikasi Bisnis dan Manajemen, 3 (3): 361-372

Firdaus, M.Y.S., \& Sjahruddin, H., 2019, Pengaruh Kompensasi dan Motivasi Terhadap Kepuasan Kerja Pegawai. Jurnal Organisasi dan Manajemen, 2 (1):1-14

Husni, Musnadi, S., \& Faisal. 2018. Pengaruh Lingkungan Kerja, Kompensasi Dan Motivasi Terhadap Kepuasan Kerja Serta Dampaknya Terhadap Loyalitas Kerja Pegawai Rutan Di Provinsi Aceh (Studi Kasus Pada Rutan Klas II B Banda Aceh Dan Rutan Klas II B Jantho. Jurnal Magister Manajemen, 2 (1): 88-98

Kalangi, R. 2015. Pengembangan Sumber Daya Manusia Dan Kinerja Aparat Sipil Negara Di Kabupaten Kepulauan Sangihe Provinsi Sulawesi Utara. Jurnal LPPM Bidang Ekososbudkum, 2 (1): 1-18

Mangkunegara, A.P. 2015. Manajemen Sumber Daya Perusahaan. Bandung: PT. Remaja Rosdakarya 
Marta, M.S., \& Budi. 2019. Lingkungan Kerja, Mungkinkah Tidak Berpengaruh Terhadap Kepuasan Kerja? Manajerial, 18 (1): 18-30

Mochklas, M \& Fatihudin, D. 2019. The Workload of Female Workers Has Very Little Effect On Career Development. Proceedings of the 1st International Conference on Business, Law And Pedagogy, ICBLP 2019, 13-15 February 2019, Sidoarjo, Indonesia. https://eudl.eu/proceedings/ICBLP/2019

Muayyad, D.M., \& Gawi, A.I.O. 2016. Pengaruh Kepuasan Kerja Terhadap Produktivitas Kerja Pegawai Bank Syariah X Kantor Wilayah II. Jurnal Manajemen Dan Pemasaran Jasa, 9 (1): 75-97

Mutia, D.Y.R. 2018. Pengaruh Motivasi, Kompetensi, Komitmen Organisasi Melalui Kepuasan Kerja Terhadap Kinerja Karyawan Di Bank Syariah Mandiri Cabang Tulungagung. Skripsi. Jurusan Perbankan Syariah Fakultas Ekonomi Dan Bisnis Islam Institut Agama Islam Negeri Tulungagung

Parimita, W., Khoiriyah, S., \& Handaru, A.W. 2018. Pengaruh Motivasi Kerja Dan Kompensasi Terhadap Kepuasan Kerja Pada Karyawan PT Tridaya Eramina Bahari. Jurnal Riset Manajemen Sains Indonesia (JRMSI), 9 (1): 125-144

Robbin, S.P. 2015. Manajemen. Jilid kedua. Edisi Indonesia, Jakarta: PT. INDEX Kelompok Gramedia

Sedarmayanti. 2011. Tata Kerja dan Produktivitas Kerja. Bandung: CV. Mandar Maju

Sitinjak, L.N. 2018. Pengaruh Lingkungan Kerja Terhadap Kepuasan Kerja Karyawan (Studi Pada Karyawan PT. Mitra Pinasthika Mustika Rent Tangerang Selatan). Jurnal Administrasi Bisnis (JAB), 60 (2): 162-168

Sudiarditha, I K R., Waspodo, A.A.W.S., \& Triani, N. A. 2016. Pengaruh Lingkungan Kerja dan Motivasi Kerja Terhadap Kepuasan Kerja Karyawan Pada Direktorat Jenderal Lembaga Penerbitan Televisi Republik Indonesia. Jurnal Manajemen, 20 (2):278-292

Susilo, J., \& Satrya, I.G.B.H. 2019. Pengaruh Kepuasan Kerja Terhadap Turnover Intention Yang Dimediasi Oleh Komitmen Organisasi Karyawan. E-Journal Management, 8 (6): 3700-3729

Sutrisno, E. 2016. Manajemen Sumber Daya Manusia. Jakarta: Prenadamedia Group

Suwardi \& Daryanto. 2018. Pedoman Praktis K3LH (Keselamatan dan Kesehatan Kerja dan Lingkungan Hidup), Yogyakarta: Gava Media 
Achmad Budi Saifudin, Didin Fatihudin, dan Mochamad Mochklas. Dampak Lingkungan Kerja....

Wibowo, T.S. \& M. Mochklas. 2020. Urgency Of Organizational Citizenship Behavior Towards Performance Of Nurses Of Type-C Hospitals In Surabaya. International Journal of Scientific \& Technology Research, 9(2):4534-4538 